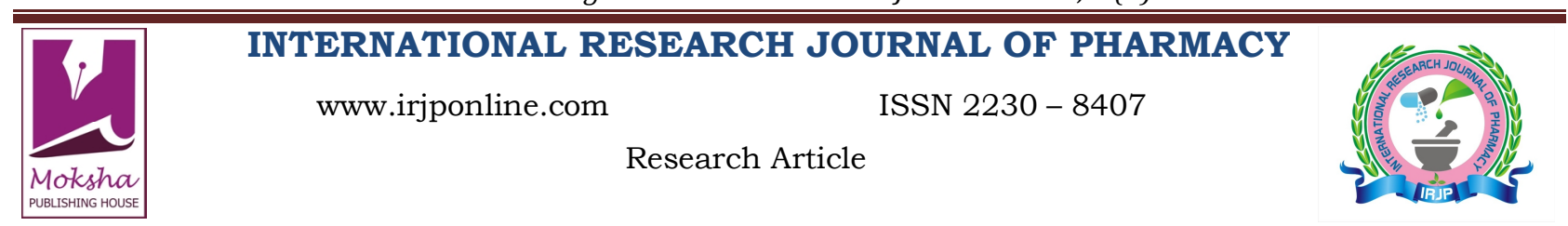

\title{
STUDY ON THE EFFECT OF GRAPE SEED PROANTHOCYANIDINS ON ADIPOCYTOKINE RECEPTORS IN DIET INDUCED FATTY LIVER DISEASE
}

\author{
Baskaran Yogalakshmi and Carani Venkatraman Anuradha* \\ Department of Biochemistry and Biotechnology, Annamalai University, Annamalai Nagar, Tamil Nadu, India \\ *Corresponding Author Email: cvaradha@hotmail.com
}

Article Received on: 16/05/13 Revised on: 11/06/13 Approved for publication: 01/07/13

DOI: $10.7897 / 2230-8407.04744$

IRJP is an official publication of Moksha Publishing House. Website: www.mokshaph.com

(C) All rights reserved.

\section{ABSTRACT}

Fatty liver is the hepatic component of the metabolic syndrome. Compelling evidence demonstrate that cytokines produced by the adipocytes play a major role in the pathogenesis of fatty liver disease. This study investigates effect of grape seed proanthocyanidins (GSP, $100 \mathrm{mg} / \mathrm{kg}$ b.w) in comparison and in combination with metformin (MET, $50 \mathrm{mg} / \mathrm{kg} \mathrm{b.w}$ ) on the mRNA levels in liver of major receptors of adipocytokines [tumor necrosis factor (TNF)- $\alpha$, interleukin (IL)-6, adiponectin and leptin] in a rat model of high fructose, fat diet (HFFD)-induced fatty liver disease. HFFD-fed rats showed increased lipid content and oxidative stress with decreased antioxidants. The mRNA levels of receptors of TNF- $\alpha$, IL- 6 and leptin were also higher whereas that of adiponectin was lower during fatty liver disease. Upon GSP and MET administration, these changes in the receptor expression of adipocytokines were reversed. When both MET and GSP were administered, the effects were observed to be more intense. Restoration of the levels of adipocytokine's receptors gives a clue, in part, of the ability of GSP and MET to combat fatty liver disease.

Keywords: Grape seed proanthocyanidins, oxidative stress, adipocytokines, receptors, fatty liver.

\section{INTRODUCTION}

Non-alcoholic fatty liver disease (NAFLD) is a chronic inflammatory state of the liver involving a wide range of disorders from steatosis, steatohepatitis, fibrosis and cirrhosis. NAFLD has been associated with many etiological factors $^{1-2}$ the most common ones being obesity and type 2 diabetes mellitus. Available evidence propose a tenable theory of NAFLD pathogenesis involving two stages, known as "two-hit theory", the first hit being excessive accumulation of lipids in the cytoplasm of liver and the second hit being injury due to oxidative stress and subsequent inflammatory reactions. ${ }^{3}$ This has now been modified as "multi hit theory" due to involvement of several other factors among which the role of pro and anti-inflammatory adipocytokines is undisputable. ${ }^{4}$ Adipocytes secrete a wide range of cytokines and at the same time express receptors for most of these factors. Adipocytokines play a major role in obesity associated insulin resistance by binding to their receptors present in liver and other target tissues. Further inflammatory cytokines are shown to be involved in the progression of NAFLD. Among various adipokines, tumor necrosis factor (TNF)- $\alpha$, interleukin (IL)-6, adiponectin and leptin are the most studied due their coherent and important effects reported thus far. TNF- $\alpha$ is recognized as the first cytokine that could induce insulin resistance. It is the most studied proinflammatory cytokine as it provides a molecular link between obesity and IR. Another cytokine with pleotropic effects is IL-6. This multi-functional cytokine, along with $\mathrm{TNF}-\alpha$, plays a major role in mediating inflammation, insulin resistance and liver regeneration. ${ }^{5}$ Leptin, a satiety hormone, regulates appetite, energy homeostasis and glucose/lipid metabolism. ${ }^{6-7}$ Adiponectin exerts profound antidiabetic and anti-inflammatory roles and is inversely correlated with BMI. $^{8-9}$ A large number of reports have demonstrated that grape seed proanthocyanidins (GSP) provide potent protection against free radical-induced diseases, such as ischemia and reperfusion injury of many organs, tumor promotion and carcinogenesis, and are highly bioavailable. Studies have shown that the antioxidant power of proanthocyanidins is 20 times greater than vitamin $\mathrm{E}$ and 50 times greater than vitamin $\mathrm{C} .{ }^{10}$ Few reports that demonstrate the effects of GSP on adipocytokines are available ${ }^{11}$ but none on their receptors. It is well documented that feeding of diet high in fructose and fat results in imbalance in energy intake and expenditure leading to fat accumulation. Imbalance in energy metabolism results in a shift to a proinflammatory state mediated by oxidative stress that advances to NASH. This investigation was therefore carried out to study the mRNA expression of receptors of these four major adipocytokines, TNF- $\alpha$, IL- 6 , adiponectin and leptin in a rat model of NAFLD. We also report the effect of GSP in comparison with MET, alone and in combination to verify whether the combination treatment is more effective.

\section{MATERIALS AND METHODS}

\section{Chemicals}

Primers were purchased from Sigma-Aldrich (Mumbai, India) and the SYBR Green-qPCR master mix was purchased from Thermo Scientific, USA. The solvents and chemicals of analytical grade were purchased from Himedia Laboratories Pvt. Ltd., Mumbai, India.

\section{Experimental Diet and Treatment}

The normal rat feed was obtained from feed supplement suppliers (Sai enterprisei, Chennai, India) which contained 60 $\%$ starch, $22.08 \%$ protein and $4.38 \%$ fat. This commercial diet provided $382.61 \mathrm{cal} / 100 \mathrm{~g}$. The high-fat/fructose diet (HFFD) prepared in our laboratory contained $45 \%$ fructose, $20 \%$ fat, (10\% beef tallow, $10 \%$ groundnut oil) and $22.5 \%$ casein and provided $471.25 \mathrm{cal} / 100$ g. Proanthocyanidinrich extract from grape seed (GSP, gravinol-Super ${ }^{\mathrm{TM}}$ ) was kindly provided by Kikkoman Co. (Chiba, Japan). The grape seed extract was composed of $89 \%$ proanthocyanidin, $6 \%$ monomers and $5 \%$ other materials. Metformin hydrochloride was obtained from the local drug store (Ranbaxy, India). 
Experimental Animals and Study Design

This study was conducted in strict accordance with the guidelines of the Committee for the Purpose of Control and Supervision on Experiments on Animals (CPCSEA). All procedures were adhered to the guidelines of the Institutional Animal Ethical Committee (IAEC) and approved. Six-weekold male albino Wistar rats $(n=6)$ were purchased from Rajah Muthiah Medical College and Hospital (RMMC and $\mathrm{H}$, Annamalai University) and were individually housed under hygienic conditions $\left(22-24^{\circ} \mathrm{C}\right)$ in polypropylene cages under $12 \mathrm{~h}$ light $/ 12 \mathrm{~h}$ dark cycle. After acclimatization for a period of 1 week, the animals were divided at random into six groups consisting of six rats each. The following groups were maintained for a total period of 45 days.

Group 1: CON - Animals received normal rat chow till the end of the experimental period.

Group 2: HFFD - Animals received high fat-high fructose diet till the end of the experimental period.

Group 3: HFFD + GSP - Animals received high fat-high fructose diet and were orally administered GSP in water (100 $\mathrm{mg} / \mathrm{kg}$ b.w./day) from day 31 till the end of the experimental period.

Group 4: HFFD + MET - Animals received high fat-high fructose diet and were orally administered MET in water (50 $\mathrm{mg} / \mathrm{kg}$ b.w./day) from day 31 till the end of the experimental period.

Group 5: HFFD + GSP + MET - Animals received high fathigh fructose diet and were orally administered GSP (100 mg / kg b.w./day) and MET (50 mg / kg b.w./day) at an interval of at least $4 \mathrm{~h}$ from day 31 till the end of the experimental period.

Group 6: CON + GSP - Animals received normal rat chow and were orally administered GSP (100 mg / kg b.w./day) from day 31 till the end of the experimental period.

Food and water were provided ad libitum to the animals. At the end of the experimental period, the rats were fasted for 18 h. After cervical decapitation, blood samples were collected in EDTA-contained tubes and centrifuged to obtain plasma Liver was removed immediately and was washed with ice cold physiological saline solution. Samples were stored at $80^{\circ} \mathrm{C}$ until further analysis.

\section{Lipid Peroxidation and Protein Carbonylation}

Lipid peroxidation was evidenced by measuring the formation of thiobarbituric acid reactive substances (TBARS) and hydroperoxides (LHP) in liver following the method of Niehaus and Samuelsson (1968) and Jiang et al. (1992) respectively. ${ }^{12-13}$ Protein damage was evidenced by measuring protein carbonyl (PC) content in liver samples following the method of Levine et al. (1990). ${ }^{14}$

\section{Assay of GSH and GPx}

The level of reduced glutathione (GSH) and activity of gluthathione peroxidase (GPx) was measured using Ellman's reagent (5'5', di thio nitro benzoic acid) by following the method of Ellman (1959) and Rotruck et al. (1973) respectively. ${ }^{16-17}$

\section{Estimation of Total Lipids}

Lipids were extracted from liver by the method of Folch et al., $(1957)^{15}$ using chloroform: methanol mixture $(2: 1 \mathrm{v} / \mathrm{v})$.
Real-Time PCR (qPCR)

Total RNA from liver was extracted using TriZol reagent. The concentration and purity of the isolated RNA were checked by measuring the absorbances at 260 and $280 \mathrm{~nm}$. Total RNA $(2.0 \mu \mathrm{g})$ was reverse transcribed to cDNA in a reaction mixture containing $1 \mu \mathrm{l}$ of Oligo $(\mathrm{dT})$ primer $(0.2 \mu \mathrm{g}$ / $\mathrm{ml}), 1 \mu \mathrm{l}$ of RNase inhibitor $(10 \mathrm{U} / \mathrm{ml}), 1 \mu \mathrm{l}$ of $0.1 \mathrm{M}$ DTT, $4 \mu \mathrm{l}$ of RT Buffer (5X), $2.0 \mu \mathrm{l}$ of $30 \mathrm{mM}$ dNTP mix $(7.5 \mathrm{mM}$ each), $0.5 \mu \mathrm{l}$ of M-MuLV Reverse Transcriptase (50 U/ $\mu \mathrm{l})$ and made up to $20 \mu \mathrm{l}$ with sterile water and kept at $37^{\circ} \mathrm{C}$ for 1 $\mathrm{h}$ and then heated at $95^{\circ} \mathrm{C}$ for 2 minutes. PCR amplification was performed in a mixture containing $100 \mu \mathrm{g}$ cDNA, $1 \mu \mathrm{l}$ each of $50 \mathrm{pM}$ of forward and reverse primers, $10 \mu \mathrm{S}$ SYBR green master mix with a final volume of $20 \mu \mathrm{l}$ made up using nuclease free water. The primer sequence used are as follows: TNF- $\alpha$ receptor 1 (TNFR1)-(F)-3'-tgcctcacactgagcatctt-5' and (R)-3'-ccccaaagtccacactcact-5'; TNF- $\alpha$ receptor 2 (TNFR2)-(F)-3'-cgctgttccaaggacaatct-5' and (R)-3'ggttgaacccaaggacacag -5'; IL-6 receptor (IL-6R)-(F)-3'gcctattgaaaatctgctctgg-5' and (R)-3'-gctctgaatgactctggcttt-5'; Leptin receptor (OB-R)-(F)-3'-cacgaggtattcgatgcaaa-5' and (R)-3'-aggctggactgctccaatta-5'; Adiponectin receptor (AdipoR2)-(F)-3'-gcttgggtctgagtggaatc-5' and (R)-3'tagagggcagctcctgtgat-5' (Sigma Aldrich, St Louis, MO, USA). The thermocycling conditions were as follows, initial denaturation $95^{\circ} \mathrm{C}$ for 10 minutes, denaturation $95^{\circ} \mathrm{C}$ for $15 \mathrm{~s}$, annealing $60 \pm 3^{\circ} \mathrm{C}$ for $30 \mathrm{~s}$ and extension $72^{\circ} \mathrm{C}$ for $30 \mathrm{~s}$ for 40 cycles. The reactions were run in triplicate for each sample. The $\mathrm{Ct}$ values obtained for each gene was normalized with that of GAPDH gene using the formula $2^{\wedge^{-\Delta \Delta C t}}$. The relative quantity was expressed in bar graphs as fold change with respect to control after normalization with GAPDH for each gene.

\section{Statistical Analysis}

Values are presented as means $\pm \mathrm{SD}$ of 6 rats for biochemical and 4 rats for qPCR analysis. All data analysis was performed with the use of SPSS statistical software 17.0. The statistical significance of differences between groups was determined by one-way ANOVA followed by the Tukey's multiple range test (TMRT). $\mathrm{P}<0.05$ was considered to indicate a statistically significant result.

\section{RESULTS}

\section{Oxidative Stress Products in Liver}

The levels of TBARS, LHP and PCO were significantly increased in the liver of HFFD-fed rats as compared to CON and the treatment groups. Administration of GSP showed significant reduction in these levels than that of MET. Of all the three treatment, combination treatment (HFFD + GSP + MET) showed more reduction as compared to HFFD fed rats. The values did not differ significantly between CON and CON + GSP (Table 1).

\section{Activity of Glutathione Peroxidase and Levels of Reduced Glutathione}

Activity of glutathione peroxidase (GPx) and levels of reduced glutathione (GSH) were significantly decreased in the liver of HFFD-fed rats as compared to control and the treatment groups. GSP administration significantly increased the levels of these antioxidants than that of MET. Combination treatment (HFFD + GSP + MET) significantly restored these levels to near normal as compared to HFFDfed rats. The values did not differ significantly between $\mathrm{CON}$ and CON + GSP (Table 2). 
Table 1: Levels of Peroxidation Indices (nmoles / mg protein) in Liver of Experimental Rats

\begin{tabular}{|c|c|c|c|c|c|c|}
\hline Parameters & CON & HFFD & HFFD + GSP & HFFD + MET & HFFD + GSP + MET & CON + GSP \\
\hline TBARS & $2.15 \pm 0.15^{\mathrm{a}}$ & $5.86 \pm 0.26^{\mathrm{b}}$ & $3.27 \pm 0.13^{\mathrm{c}}$ & $4.11 \pm 0.19^{\mathrm{d}}$ & $2.99 \pm 0.18^{\mathrm{e}}$ & $2.09 \pm 0.10^{\mathrm{a}}$ \\
\hline LHP & $1.58 \pm 0.04^{\mathrm{a}}$ & $4.73 \pm 0.25^{\mathrm{a}}$ & $2.52 \pm 0.12^{\mathrm{c}}$ & $3.87 \pm 0.29^{\mathrm{d}}$ & $2.12 \pm 0.22^{\mathrm{e}}$ & $1.57 \pm 0.07^{\mathrm{a}}$ \\
\hline PCO & $3.65 \pm 0.14^{\mathrm{a}}$ & $8.44 \pm 0.50^{\mathrm{a}}$ & $5.46 \pm 0.39^{\mathrm{c}}$ & $7.02 \pm 0.56^{\mathrm{d}}$ & $5.19 \pm 0.47^{\mathrm{e}}$ & $3.41 \pm 0.16^{\mathrm{a}}$ \\
\hline
\end{tabular}

CON- Control, HFFD- High fat, fructose diet, HFFD + GSP- High fat, fructose diet + grape seed proanthocyanidins, HFFD + MET - High fat, fructose diet + metformin, HFFD + GSP + MET - High fat, fructose diet + grape seed proanthocyanidins + metformin, CON+GSP - Control + grape seed proanthocyanidins.

Values are means \pm SD of 6 rats from each group. Values that bear different alphabets in their superscript differ significantly from each other. One way ANOVA followed by TMRT. A value that has $\mathrm{p}<0.05$ is considered statistically significant.

Table 2: Activities and Levels of GPx and GSH in Liver

\begin{tabular}{|c|c|c|c|c|c|c|}
\hline Parameters & CON & HFFD & HFFD + GSP & HFFD + MET & HFFD + GSP + MET & CON + GSP \\
\hline GPx (A) & $6.87 \pm 0.24^{\mathrm{a}}$ & $4.41 \pm 0.2^{\mathrm{b}}$ & $5.89 \pm 0.31^{\mathrm{c}}$ & $5.06 \pm 0.26^{\mathrm{d}}$ & $6.21 \pm 0.41^{\mathrm{e}}$ & $6.99 \pm 0.31^{\mathrm{a}}$ \\
\hline GSH (B) & $10.7 \pm 0.35^{\mathrm{a}}$ & $5.7 \pm 0.21^{\mathrm{b}}$ & $7.6 \pm 0.41^{\mathrm{c}}$ & $6.1 \pm 0.27^{\mathrm{d}}$ & $8.7 \pm 0.39^{\mathrm{e}}$ & $11.0 \pm 0.86^{\mathrm{a}}$ \\
\hline
\end{tabular}

Treatment and comparisons are as given in Table $1 . \mathrm{A}=\mu$ moles of $\mathrm{GSH}$ utilised $/ \mathrm{min} / \mathrm{mg}$ protein; $\mathrm{B}=\mu \mathrm{g} / \mathrm{mg} \mathrm{protein}$.

Table 3: Content of Total Lipids in Liver ( $\mathrm{mg} / \mathrm{g}$ tissue)

\begin{tabular}{|l|c|c|c|c|c|c|}
\hline Parameters & CON & HFFD & HFFD + GSP & HFFD + MET & HFFD + GSP + MET & CON + GSP \\
\hline Total Lipids & $92 \pm 4.51^{\mathrm{a}}$ & $241 \pm 19.2^{\mathrm{b}}$ & $162 \pm 9.53^{\mathrm{c}}$ & $213 \pm 15.2^{\mathrm{d}}$ & $171 \pm 12.9^{\mathrm{e}}$ & $90 \pm 5.12^{\mathrm{a}}$ \\
\hline
\end{tabular}
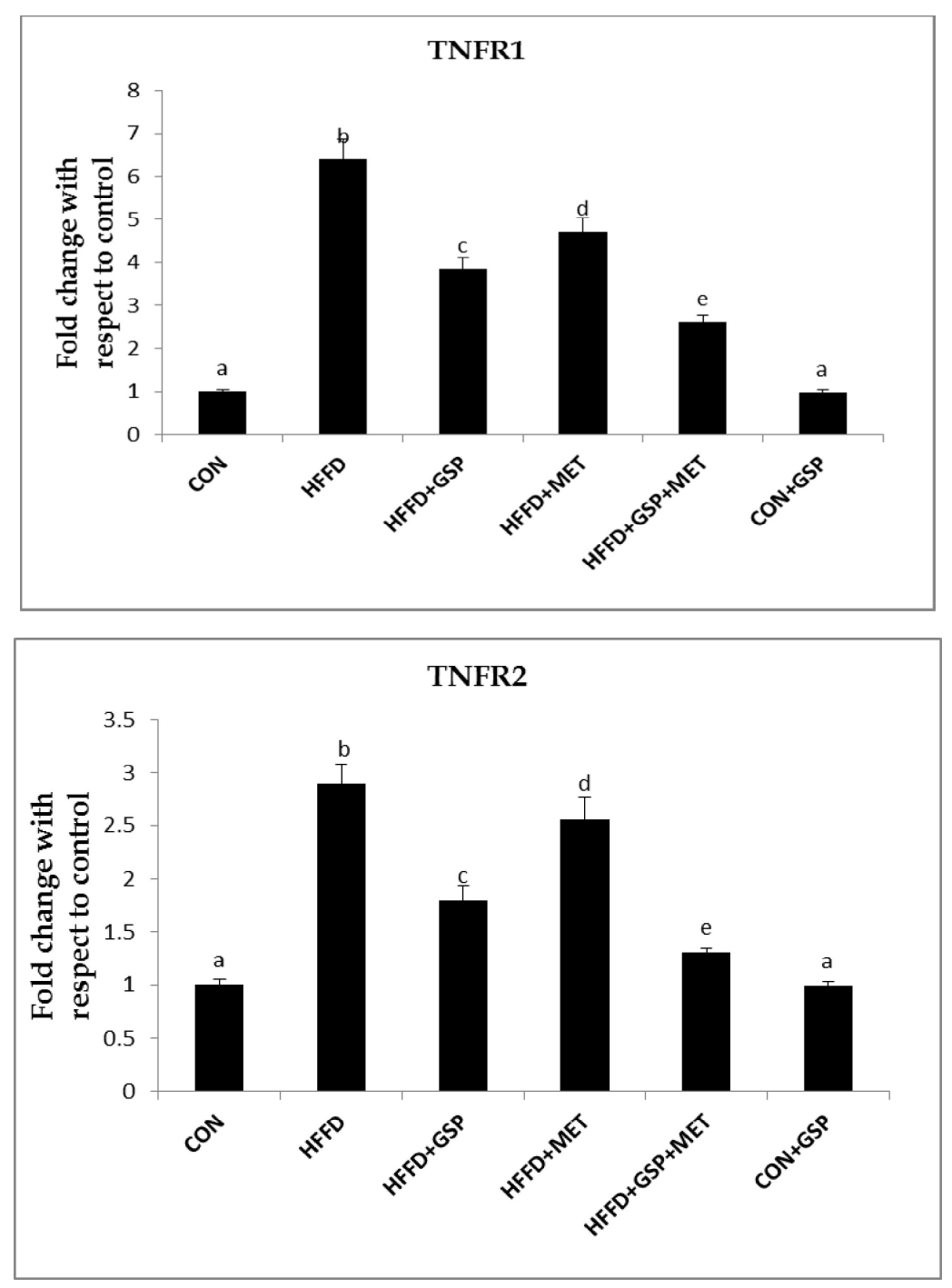

Figure 1: mRNA expression of TNFR1 and R2. Values are means \pm SD of 4 rats from each group. Values that bear different alphabets in their superscript differ significantly from each other. One way ANOVA followed by TMRT. A value that has $p<0.05$ is considered statistically significant. 


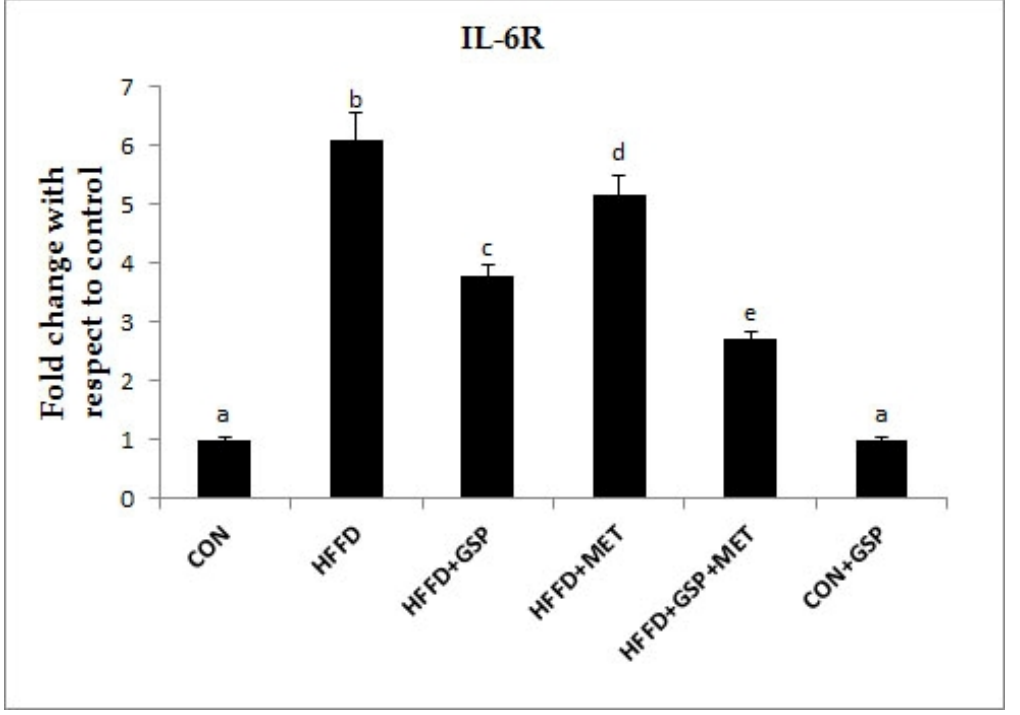

Figure 2: mRNA expression of IL-6 receptor. Values are means \pm SD of 4 rats from each group. Values that bear different alphabets in their superscript differ significantly from each other. One way ANOVA followed by TMRT. A value that has $p<0.05$ is considered statistically significant.

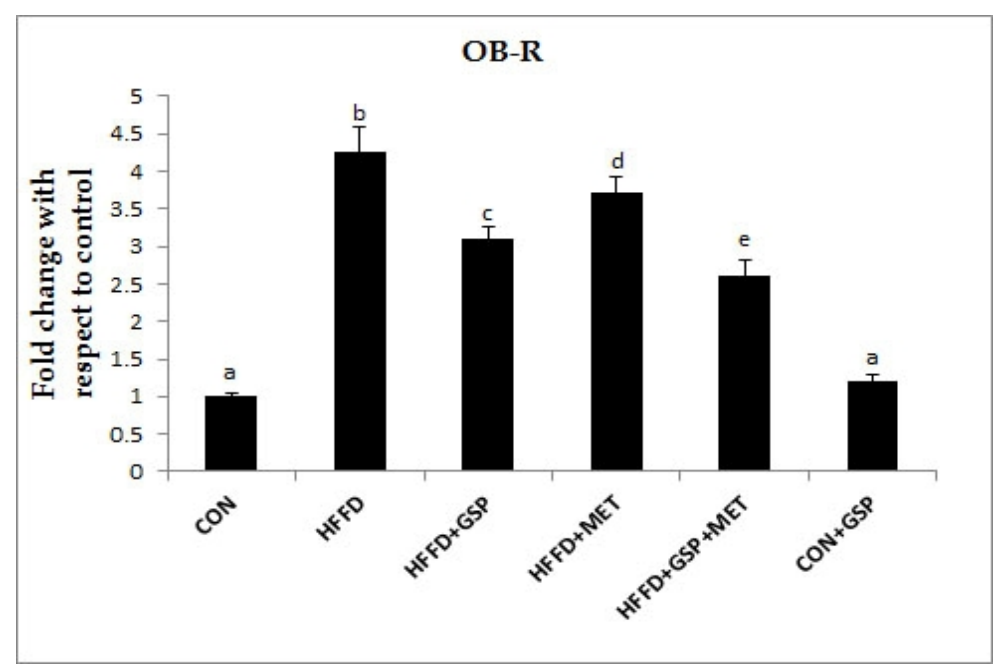

Figure 3: mRNA expression of leptin receptor. Values are means \pm SD of 4 rats from each group. Values that bear different alphabets in their superscript differ significantly from each other. One way ANOVA followed by TMRT. A value that has $p<0.05$ is considered statistically significant.

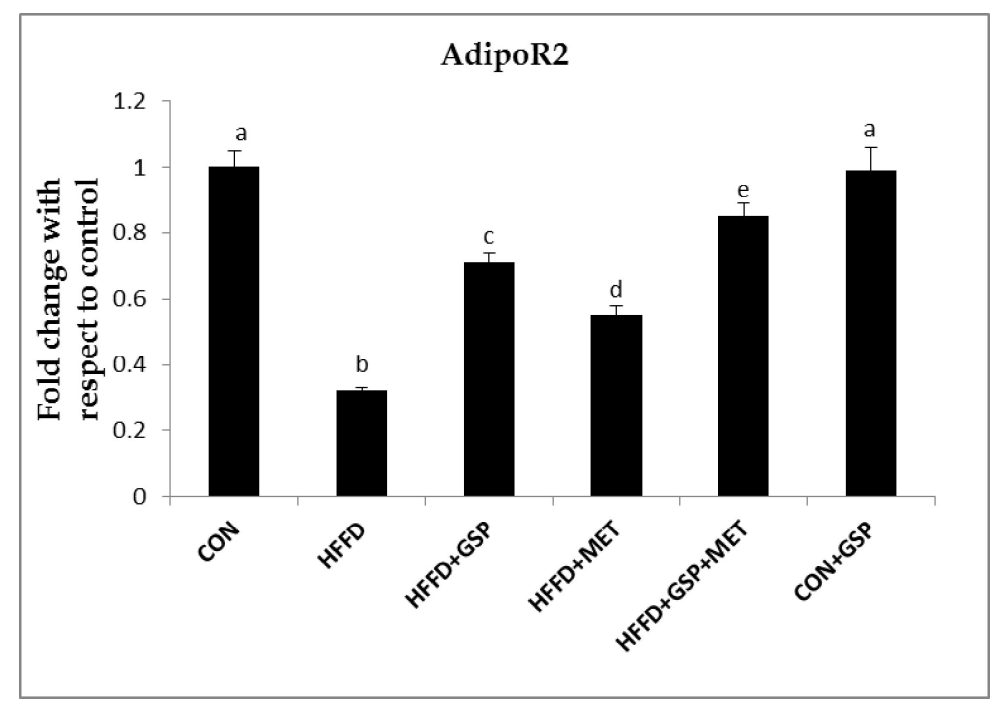

Figure 4: mRNA expression of adiponectin receptor. Values are means \pm SD of 4 rats from each group. Values that bear different alphabets in their superscript differ significantly from each other. One way ANOVA followed by TMRT. A value that has $p<0.05$ is considered statistically significant. 
Levels of Total Lipids

The amount of total lipids was found to be high in rats fed HFFD alone compared to other groups. Administration of GSP and MET, alone and in combination reduced these levels to significant levels (Table 3).

\section{mRNA Expression of Receptors of Adipocytokines}

Rats fed HFFD showed a significant up regulation of TNFR1 and R2 to 6.4 and 2.9 folds respectively as compared to CON. Supplementation of GSP, MET and combination treatment significantly reduced the mRNA expression of TNFR1 to 3.85, 4.71 and 2.62 folds and TNFR2 to 1.8, 2.56 and 1.31 folds respectively as compared to CON (Figure 1). Increased mRNA expression of IL-6R by 6.12 fold was observed in HFFD-fed rats as compared to control. Supplementation of GSP, MET and combination treatment significantly reduced the mRNA expression of IL-6R to 3.8, 5.16 and 2.72 folds respectively as compared to CON (Figure 2 ). HFFD fed rats showed significant increase in the mRNA expression of OB-R to 4.26 fold as compared with CON. Supplementation of GSP, MET and combination treatment reduced the expression of OB-R to $3.11,3.71$ and 2.6 folds respectively as compared to CON (Figure 3 ). The mRNA expression of adipoR2 was observed to be decreased to 0.32 fold during HFFD feeding. These were reversed upon GSP and MET supplementation to 0.71 and 0.55 folds of expression respectively. Combination showed significant up regulation of adiponectin receptor and increased its expression to 0.85 fold (Figure 4). HFFD-fed rats showed maximum susceptibility to chronic hepatic inflammation indicated by the up regulation of proinflammatory cytokine receptors and down regulation of anti-inflammatory cytokine receptors. On comparing between the individual treatments, GSP showed better reduction in inflammation than MET.

\section{DISCUSSION}

NAFLD develops as a companion of the metabolic syndrome and is associated with excess of proinflammatory cytokines in plasma that activate inflammatory response in the liver through the receptors found on the hepatic cell surface. In the present study we have demonstrated that GSP and MET decreased the expression of adipocytokine receptors in liver of rats with fatty liver disease. Lipid retention within hepatocytes triggers oxidative stress (the "second hit") generating reactive oxygen species (ROS) at different intracellular levels. Most lipid peroxides, formed in cells due to intracellular ROS diffuse and may reach sites distant from those of generation and cause tissue damage and macrophage activation thereby provoking inflammation. ${ }^{18}$ In this respect, it has been observed that subjects with steatohepatitis show high hepatic and systemic levels of lipid peroxidation products. In concordance with this, we observed increased total lipids, oxidative stress (TBARS, LHP and PCO, the byproducts of lipid and protein peroxidation) and reduced antioxidants (GPx and GSH) in liver of HFFD group of rats. GSP being a powerful antioxidant by itself might have helped to replenish the antioxidant defense and thus suppressed the levels of peroxidation products. MET also reduced oxidative stress but not as effective as GSP. The combined administration of GSP and MET brought down the levels of oxidative stress markers even lower than that of GSP and MET alone. Bioactive cytokines are released from the adipose tissue in response to increased damage by free radicals and their byproducts. These include several novel and highly active molecules like leptin, resistin, adiponectin or visfatin, as well as some more classical cytokines released possibly by inflammatory cells infiltrating fat, like TNF- $\alpha$ and IL-6. ${ }^{19}$ The most abundantly expressed within the adipose tissue are leptin and adiponectin. These cytokines play a major role in the progression of fatty liver to the next stage of steatohepatitis. Adiponectin is the most interesting and promising cytokine for the clinicians since it has profound protective effects as anti-inflammatory, vasculoprotective, and anti-diabetic. Adiponectin is low in obese subjects and, in particular, insulin-resistant patients. ${ }^{20}$ It is shown to suppress the proliferation and activation of immune cells and inflammatory cytokines such as TNF- $\alpha$ during fatty liver disease. ${ }^{21}$ Besides these direct effects, adiponectin exerts further beneficial actions by lowering dyslipidemia and other risk factors of NAFLD. ${ }^{22-23}$ The effects of adiponectin in liver are mediated by its receptor AdipoR2, and in skeletal muscle by AdipoR1. Since obesity decreases the expression levels of adiponectin receptor, regulation of adiponectin action, at least in part, can occur via controlling the expression of adipoR2. In the present study, HFFD feeding had decreased the expression of adipoR2 while GSP and MET administration had improved these levels at a genetic level. Though GSP showed a more pronounced effect than MET in improving adipoR2 expression, combined treatment showed maximum improvement than GSP or MET alone. Leptin drew substantial research attention for the past 20 years. Leptin, a 167 amino-acid protein, encoded by the ob gene, belongs to a cytokine family, located within $7 \mathrm{q} 31.3$ locus. ${ }^{24}$ OB-R are expressed in number of different tissues, which brought the attention of researchers due to the fact that leptin has a very widespread range of actions. ${ }^{25-27}$ Ubiquitous expression of the receptors and widespread binding of leptin in various organs indicates its role in a constellation of vital processes including growth, metabolic control, immune regulation and insulin sensitivity regulation. Higher levels of this hormone along with increased receptor expression denote leptin resistance which is commonly reported under conditions of obesity. TNF- $\alpha$ and IL-6 are potent proinflammatory cytokines that are known to increase the release of leptin from adipocytes. ${ }^{28-29}$ This is the first study on the effects of GSP and MET administration on receptors of adipocytokines under HFFD-feeding to rats. The mRNA levels of receptors of TNF- $\alpha$, IL- 6 and leptin were found to be very high and that of adiponectin was low in liver during HFFD feeding. The mRNA expression of receptors is induced in response to the circulating protein levels. We also observed increased plasma concentrations of TNF- $\alpha$, IL- 6 and leptin and decreased levels of adiponectin (unpublished data) in HFFD group of rats. GSP and MET administration restored the mRNA levels of the receptors. Combined administration of both has resulted in near normal level of the receptors. The importance of inflammation must be considered while in search of a novel drug for suppressing fatty liver disease. Hence any drug that controls the expression of inflammatory adipocytokines or their receptors may be vouched to have good potential as treatment for NAFLD. In this regard, our results clearly indicate the role played by GSP and MET alone and in combination in regulating the levels of the receptors of adipocytokines. Hence GSP alone or in combination with MET may be taken to the next level of research for developing a pharmacological therapy for NAFLD with additional studies on the molecular details of their actions. 
ACKNOWLEDGEMENT

We sincerely acknowledge Indian Council of Medical Research (ICMR), New Delhi, India for the financial support given to the first author Yogalakshmi B in the form of Senior Research Fellowship (SRF).

\section{REFERENCES}

1. McCullough AJ. Update on nonalcoholic fatty liver disease. J Clin Gastroenterol 2002; 34(3): 255-62. http://dx.doi.org/10.1097/00004836200203000-00013 PMid:11873108

2. Angulo P. Nonalcoholic fatty liver disease. N Engl J Med 2002; 346(16):1221-31.http://dx.doi.org/10.1056/NEJMra011775 PMid: 11961152

3. James OF, Day CP. Non-alcoholic steatohepatitis (NASH): a disease of emerging identity and importance. J Hepatol 1998; 29(3): 495-501. http://dx.doi.org/10.1016/S0168-8278(98)80073-1

4. Polyzos SA, Kountouras J, Zavos C. Nonalcoholic fatty liver disease: the pathogenetic roles of insulin resistance and adipocytokines. Curr Mol Med 2009; 9(3): 299-314. http://dx.doi.org/10.2174 /156652409787847191 PMid: 19355912

5. Streetz KL, Luedde T, Manns MP, Trautwein C. Interleukin 6 and liver regeneration. Gut 2000; 47(2): 309-12. http://dx.doi.org/10.1136/gut. 47.2.309 PMid:10896929 PMCid:PMC1727989

6. Havel PJ. Control of energy homeostasis and insulin action by adipocyte hormones: leptin, acylation stimulating protein and adiponectin. Curr. Opin. Lipidol 2002; 13: 51-9. http://dx.doi.org/10.1097/00041433200202000-00008 PMid:11790963

7. Havel PJ. Update on adipocyte hormones: regulation of energy balance and carbohydrate/ lipid metabolism. Diabetes 2004; 53(Suppl 1): S14351. http://dx.doi.org/10.2337/diabetes.53.2007.S143 PMid:14749280

8. Kadowaki $\mathrm{T}$, et al. Adiponectin and adiponectin receptors in insulin resistance, diabetes and the metabolic syndrome. J. Clin. Invest 2006; 116: 1784-92. http://dx.doi.org/10.1172/JCI29126 PMid:16823476 PMCid:PMC1483172

9. Yan E, et al. Insulin, hs-CRP, leptin and adiponectin. An analysis of their relationship to the metabolic syndrome in an obese population with an elevated waist circumference. Metab. Syndr. Relat. Disord 2008; 6: 64-73. http://dx.doi.org/10.1089/met.2007.0027 PMid:18370838

10. Shi J, Yu J, Pohorly JE, Kakuda Y. Polyphenolics in grape seedsbiochemistry and functionality. J Med Food 2003; 6(4): 291-9. http://dx.doi.org/10.1089/109662003772519831 PMid:14977436

11. WG Li, XY Zhang, YJ Wu, X Tian. Anti-inflammatory effect and mechanism of proanthocyanidins from grape seeds. Acta Pharmacol Sin 2001; 22(12): 1117-20. PMid:11749811

12. Niehaus WG Jr, Samuelsson B. Formation of malonaldehyde from phospholipid arachidonate during microsomal lipid peroxidation. Eur J Biochem 1968; 6: 126-30. http://dx.doi.org/10.1111/j.14321033.1968.tb00428.x PMid:4387188

13. Jiang ZY, Hunt JV, Wolf SP. Detection of lipid hydroperoxides using Fox method. Anal. Biochem 1992; 202: 384-9. http://dx.doi.org/ 10.1016/0003-2697(92)90122-N

14. Levine RL, Garland D, Oliver CN, Amici A, Climent I, Lenz AG, Ahn BW, Shaltiel S, Stadtman ER Determination of carbonyl content in oxidatively modified proteins. Methods Enzymol 1990; 186: 464-78. http://dx.doi.org/10.1016/0076-6879(90)86141-H

15. Folch J, Lees M, Sloane Stanley GH. A simple method for the isolation and purification of total lipids from animal tissues. J Biol Chem 1957; 226: 497-509. PMid:13428781
16. Ellman GL. Tissue sulfhydryl groups. Arch Biochem Biophys 1959; 82 : 70-7. http://dx.doi.org/10.1016/0003-9861(59)90090-6

17. Rotruck JT, Pope AL, Ganther HE, Swanson AB, Hafeman DG, Hoekstra WG. Selenium: biochemical role as a component of glutathione peroxidase. Science 1973; 179: 588-90. http://dx.doi.org /10.1126/science.179.4073.588 PMid:4686466

18. Casini A, Ceni E, Salzano R, Biondi P, Parola M, Galli A, Foschi M, Caligiuri A, Pinzani M, Surrenti C. Neutrophil-derived superoxide anion induces lipid peroxidation and stimulates collagen synthesis in human hepatic stellate cells: role of nitric oxide. Hepatology 1997; 25(2): 3617. http://dx.doi.org/10.1002/hep.510250218 PMid:9021948

19. Tilg H, Moschen AR. Adipocytokines: mediators linking adipose tissue, inflammation and immunity. Nat Rev Immunol 2006; 6: 772-783. http://dx.doi.org/10.1038/nri1937 PMid:16998510

20. Matsuzawa Y, Funahashi T, Kihara S et al. Adiponectin and metabolic syndrome. Arterioscler Thromb Vasc Biol 2004; 24: 29-33. http:/ /dx.doi.org/10.1161/01.ATV.0000099786.99623.EF PMid:14551151

21. Fantuzzi G. Adipose tissue, adipokines and inflammation. J Allergy Clin Immunol 2005; 115: 911-919. http://dx.doi.org/10.1016 /j.jaci.2005.02.023 PMid:15867843

22. Tsao TS, Murrey HE, Hug C, Lee DH, Lodish HF. Oligomerization state-dependent activation of NF-kappa B signaling pathway by adipocyte complement-related protein of $30 \mathrm{kDa}$ (Acrp30). J Biol Chem 2002; 277: 29359-29362. http://dx.doi.org/10.1074/jbc.C200312200 PMid: 12087086

23. Yamauchi T, Kadowaki T. Physiological and pathophysiological roles of adiponectin and adiponectin receptors in the integrated regulation of metabolic and cardiovascular diseases. Int J Obes (Lond) 2008; 32(Suppl 7): S13-S18. http://dx.doi.org/10.1038/ijo.2008.233 PMid:19136982

24. Geffroy S, De Vos P, Staels B, Duban B, Auwerx J, De Martinville B. Localization of the human OB gene (OBS) to chromosome $7 \mathrm{q} 32$ by fluorescence in situ hybridization. Genomics 1995; 28: 603-604. http://dx.doi.org/10.1006/geno.1995.1201 PMid:7490107

25. Matyjek R, Kapica M, Puzio J, Babelewska M, Zabielski R. The effect of fundectomy on pancreatic secretion in anaesthetized rats. J Physiol Pharmacol 2004; 55(Suppl 2): 69-75. PMid:15608362

26. Krolczyk G, Laskiewicz J, Sobocki J, Matyja A, Kolasinska Kloch W, Thor PJ. The effects of baclofen on the feeding behavior and body weight of vagally stimulated rats. J Physiol Pharmacol 2005; 56: 121131. PMid: 15795480

27. Kaminski T, Smolinska N, Gajewska A, et al. Leptin and long form of leptin receptor genes expression in the hypothalamus and pituitary during the luteal phase and early pregnancy in pigs. J Physiol Pharmacol 2006; 57: 95-108. PMid:16601318

28. Finck BN, Johnson RW. Tumor necrosis factor (TNF)-alpha induces leptin production through the p55 TNF receptor. Am J Physiol Regul Integr Comp Physiol 2000; 278(2): R537-43. PMid:10666158

29. Trujillo ME, Sullivan S, Harten I, Schneider SH, Greenberg AS, Fried SK. Interleukin-6 regulates human adipose tissue lipid metabolism and leptin production in vitro. J Clin Endocrinol Metab 2004; 89(11): 557782. http://dx.doi.org/10.1210/jc.2004-0603 PMid:15531514

Cite this article as:

Baskaran Yogalakshmi and Carani Venkatraman Anuradha. Study on the effect of grape seed Proanthocyanidins on adipocytokine receptors in diet induced fatty liver disease. Int. Res. J. Pharm. 2013; 4(7):197-202 http:// dx.doi.org/10.7897/2230-8407.04744 